\title{
BIBLIA I FILOZOFIA W KONFRONTACJI BAZYLEGO WIELKIEGO Z APOLINARYZMEM
}

W połowie IV w. coraz szersze kręgi zataczała doktryna Apolinarego, biskupa Laodycei, gorącego zwolennika nurtu aleksandryjskiego w chrystologii i obrońcy nicejskiego wyznania wiary, w szczególności jego kluczowego określenia ó tu doktrynalnego w Kościele, który stawiał wyzwania natury apologetycznej. W przypadku Laodycejczyka ma się także do czynienia z mistrzem egzegezy, chociaż trudno o niej coś bliższego powiedzieć ze względu na fragmentaryczność zachowanych jego dzieł poruszających kwestie biblijne ${ }^{1}$. Natomiast jeśli chodzi o pisma teologiczne Apolinarego, kwestia przedstawia się nieco inaczej. W związku z falsyfikacjami dokonanymi przez uczniów Laodycejczyka, pozostało więcej materiału pochodzącego z jego dzieł². Interpretacja Apolinarego charakteryzuje się zwięzłością formy i oszczędnym komentarzem najważniejszych punktów tekstu biblijnego. Pod względem metodologii egzegetycznej nie miano mu nic do zarzucenia. Mimo to jego przeciwnicy określali niektóre jego poglądy dotyczące eschatologii jako ,judaizm heretycki”3. To jakby uboczny skutek polemik doktrynalnych, wskazujący na swoistą ,schizofrenię" jego myśli teologicznej".

" Dr hab. Mieczysław C. Paczkowski OFM, prof. UMK - profesor nadzwyczajny w Katedrze Historii Kościoła i Patrologii na Wydziale Teologicznym Uniwersytetu Mikołaja Kopernika w Toruniu; e-mail: celestyn@umk.pl.

${ }^{1}$ Lista fragmentów dzieł egzegetycznych Apolinarego: CPG 3680-3695.

${ }^{2}$ Dzieła Apolinarego przechowano nawet pod imieniem papieża Juliusza i Atanazego.

${ }^{3}$ Por. Hieronymus, Commentariorum in Danielem III 9, 24, 126-617, ed. F. Glorie, CCL 75A, Turnhout 1964, 865-889. Bazyli opisuje niektóre elementy doktryny apolinarystycznej, stanowiące dowód na powrót do judaizmu: „O zmartwychwstaniu napisał on wymysły trącące brednią, czy raczej judaizmem, bo orzeka w nich, że winniśmy znów nawrócić do tego prawowitego kultu, znów poddawać się obrzezaniu, przestrzegać szabatu, zachowywać wstrzemięźliwość od pewnych potraw, składać Bogu ofiary ze zwierząt, oddawać Mu cześć w jerozolimskiej świątyni, a w ogóle z chrześcijan stać się żydami. Czyż od tych pomysłów może być coś bardziej śmiesznego, a raczej coś bardziej obcego ewangelicznemu dogmatowi?" (Basilius Caesariensis, Epistula 263, 4, ed. Y. Courtonne, III, Paris 1966, 124-125, tłum. W. Krzyżaniak: Św. Bazyli Wielki, Listy, Warszawa 1972, 331. Por. tenże, Epistula 265, 2.

${ }^{4}$ Wydaje się, że to przede wszystkim wydarzenia historyczne skłoniły Apolinarego do tego typu refleksji, bowiem próba odbudowy świątyni w Jerozolimie przez Juliana Apostatę obudziła nadzieje 
Apolinary poświęcił się bez reszty sprawie zwalczania tez ariańskich. Sprowokowany przez błędnowierców, odmawiających pełnego bóstwa Chrystusowi, stworzył koncepcję osoby Zbawiciela, poważnie naruszającą jego człowieczeństwo ${ }^{5}$. Zbyt jednostronny akcent położony przez Laodycejczyka na jedność w Chrystusie sprawił, że w chrystologii przekroczył on granice ortodoksji, prowokując energiczną reakcję różnych środowisk, która ostatecznie doprowadziła do jego potępienia ${ }^{6}$. Bazyli twierdził, że błąd Apolinarego bazował na „sofistycznych wypowiedziach” i powoływaniu się ,jakoby na świadectwo Pisma [Świętego]”’

1. Ogólny kontekst sporu. Kryzys związany z postulatami Apolinarego wybuchł w latach 70. IV w. i to wtedy Bazyli Wielki podjął polemikę z biskupem Laodycei. Kapadocczyk zmierzył się z kwestią apolinarystyczną w ostatnich trzech latach swego życia (pomiędzy 375 a 378). Wtedy niewiele już pisał. W listach Bazylego można jednak dostrzec poszczególne fazy jego polemiki ${ }^{8}$.

Bazyli nie rzuca wiele światła na problem pochodzenia apolinaryzmu', lecz bardzo ogólnie krytykuje jego błędne założenia ${ }^{10}$. Kapadocczyk ociagał się z otwartym potępieniem Apolinarego. Chodziło przecież o doktrynę będącą wynikiem przemyśleń cenionego egzegety, uznanego wówczas znawcy kwestii teologicznych. Biskup Cezarei uzasadniał konieczność polemiki stwierdzeniem: „Jego wywody teologiczne nie opierają się na dowodach z Pisma Świętego, ale biorą się z ludzkich urojeń"11.

Jako biskup Apolinary nie omieszkał uczynić oficjalnymi swoich twierdzeń. To właśnie czyniło jego doktrynę jeszcze bardziej niebezpieczną ${ }^{12}$. Korespondencja Bazylego pośrednio o tym świadczy. W Listach 260, 261 i 262 (kolejno do: biskupa Optymusa, mieszkańców Sozopolis i mnicha Urbicjusza), datowanych na 377 r., Kapadocczyk konfrontuje się z błędami apolinarystycznymi. W świetle wzmianek epistolarnych zawierają się one w trzech zasadach:

rychłego nastania okresu pomyślności i odnowy Izraela. Por. J.-N. Guinot, Théodoret et le millénarisme d'Apollinaire, ASE 15 (1998) fasc. 1, 177.

${ }^{5} \mathrm{Na}$ temat doktryny apolinarystycznej zob. A. Grillmeier, Christ in Christian Tradition, transl. J. Bowden, London 1965, 220-233; J.N.D. Kelly, Poczatki doktryny chrześcijańskiej, thum. J. Mrukówna, Warszawa 1988, 217-221; Ch.A. Beeley, The Early Christological Controversy: Apollinarius, Diodore, and Gregory Nazianzen, VigCh 65 (2011) 378-395; M. Pyc, Apolinaryzm w kontekście sporu o integralność człowieczeństwa Jezusa Chrystusa, „Teologia w Polsce” 6 (2012) fasc. 2, 5-16.

${ }^{6}$ Potępiły go synody rzymskie w 377 i 382 r. oraz Sobór Konstantynopolitański I (381).

${ }^{7}$ Basilius Caesariensis, Epistula 261, 1, ed. Courtonne, III, s. 115-116, thum. Krzyżaniak, s. 323.

${ }^{8}$ Por. A. Capone, Apollinaris, Basil and Gregory of Nyssa, ZACh 17 (2013) 315-319.

${ }^{9}$ Kwestia ta nie została jeszcze w pełni rozwiązana.

${ }^{10}$ Por. głównie Epistulae 263 i 265.

${ }^{11}$ Basilius Caesariensis, Epistula 263, 4, ed. Courtonne, III, s. 124, thum. Krzyżaniak, s. 331.

${ }^{12} \mathrm{Na}$ temat geograficznego zasięgu sporu zob. A. Capone, Apollinarismo e geografia ecclesiastica, w: Temi e forme della polemica in età cristiana (III-V secolo), a cura di M. Marin - M. Veronese, Auctores Nostri 9, Bari 2012, 466-467. 
Chrystus jest określany mianem „człowieka niebieskiego”, bowiem przyją niebiańskie ciało $^{13}$, dlatego z powodu wcielenia natura Boska jakoby ,zmieniła się", a w osobie wcielonego Syna Bożego nie można mówić o integralności Jego ludzkiej natury. To dyskusje au rebours polemik z arianami. Spory o wcielenie i sposób istnienia Zbawiciela Kapadocczyk ujął w szerszym kontekście.

„Ludzie nie ustają w sporach, co do wcielenia Pana, bo jedni przesądzają, że przybrał On ciało, a drudzy obstają, że przyjście Jego nastąpiło bezcieleśnie, jedni głoszą, że miał On ciało podległe cierpieniom, a drudzy znów, że spełnił swoje zadanie pozornie, jedni, że miał On ciało ziemskie, a inni znów, że ciało niebiańskie ${ }^{14}$, jedni, że istnieje On odwiecznie, a inni znów, że wziął początek od Maryi, «na znak, któremu sprzeciwiać się będą» (Łk 2, 34)"15.

Bazyli zdawał sobie sprawę, że kwestia chrystologiczna była o wiele bardziej kompleksowa, niż mogłoby się wydawać pobieżnemu obserwatorowi. Przecież wcześniej Laodycejczyk podjął zadanie obrony egzystencjalnej i dynamicznej jedności w Jezusie Chrystusie. Czynił to dokładnie i ze znawstwem. Wiele z tez Apolinarego ze względu na szczupłość zachowanego materiału może być tylko hipotyzowanych. Zachowane fragmenty o charakterze teologicznym mają w większości charakter ortodoksyjny. Chodzi rzecz jasna o 2. poł. IV w., a nie okres późniejszy. Biskup Laodycei podkreślał jedność pomiędzy bóstwem a człowieczeństwem poprzez ideę ,jednej natury" wcielonego Słowa. Te formuły chrystologiczne stały się z czasem niezwykle kontrowersyjne, nie tylko ze względy na osobę ich autora. Bazyli, tak silnie podkreślający konkretne aspekty wcielenia Słowa, nie mógł zignorować tez Apolinarego, bowiem wprowadził on ,ryzykowne i niejasne spekulacje dotyczące wcielenia"16. Prawda o obecności Logosu w ludzkim ciele stała się „,znakiem sprzeciwu".

Wcześniej Euzebiusz z Cezarei w polemice z Marcelim z Ancyry odrzucał myśl o istnieniu duszy ludzkiej w Chrystusie. Przekonania Marcelego wskazywały na to, że Chrystus był zwykłym człowiekiem, złożonym z duszy i ciała, nie różniącym się pod żadnym względem od innych ludzi, jeśli chodzi o „wspólną dla wszystkich naturę" ${ }^{17}$. Należy nadmienić, że palestyński biskup nie był prekursorem apolinaryzmu, bowiem starał się wykazać rozróżnienie

${ }^{13}$ Por. Apollinarius, Recapitulatio (Anakephalaiosis) 4, ed. H. Lietzmann, w: Apollinaris von Laodicea und seine Schule, TU, Tübingen 1904, 243, tłum. własne: „Każdy człowiek jest ziemski. Lecz Chrystus nie jest ziemski, lecz niebieski. Tak więc nie jest [On] [...] człowiekiem, jeśli pod określeniem «człowiek» nie rozumie się samej rzeczywistości [niebieskiej]”.

14 To Fotyn, powołujący się na 1 Kor 15,47 , głosił tezę o niebieskim ciele Chrystusa. Por. Epiphanius, Panarion III 71, 3, 1-5, ed. K. Holl - J. Dummer, GCS 37, Berlin 1985, 258, 6 - $259,4$.

${ }^{15}$ Basilius Caesariensis, Epistula 260, 8, ed. Courtonne, III, s. 114, tłum. Krzyżaniak, s. 321.

16 Tenże, Epistula 265, 2, ed. Courtonne, III, s. 130. Słowa te biskup kapadocki kieruje do biskupów Egiptu na wygnaniu.

${ }^{17}$ Por. Eusebius Caesariensis, De ecclesiastica theologia I 20, 43, ed. E. Klostermann, GCS 14, Leipzig 1906, 88. 
natur w osobie Zbawiciela, używając jednak terminologii sugerującej ich pomieszanie. Był to typowy błąd apolinarystów ${ }^{18}$, a później monofizytów ${ }^{19}$.

Nieprzypadkowo jednak Bazyli w swoich Listach nie od razu wymienia z imienia Apolinarego lub któregoś z jego uczniów. W grę wchodził nie tylko charakter Kapadocczyka, czy uczucie wdzięczności, ale swego rodzaju zobowiązanie związane ze wspólnymi refleksjami i przyjaźnią. Fakt odkrycia, że oto Apolinary stał się przeciwnikiem musiał być dla Bazylego bardzo bolesny. Póki więc można było zachować milczenie, nasz autor to robił, podobnie jak w przypadku błędów Eustacjusza z Sebaste czy hierarchów niezdecydowanych w kwestiach pneumatologicznych. $Z$ czasem, głównie z powodów pastoralnych i doktrynalnych, stało się to niemożliwe. Apolinary „,spowodował tym większe nasze cierpienie, ponieważ na początku wydawało się, że należał do nas" ${ }^{20}$. Laodycejczyk zostaje nazwany

„siewcą zamętu [...], [który] sprawia Kościołom utrapienia. Dzięki bowiem łatwości wypowiadania się na piśmie, obdarzony swadą w podejmowaniu każdego zagadnienia, zasypał on kraj swymi dziełami, puszczając koło uszu przestrogę tego, który mówi: «Strzeż się spisywać wiele ksiag» (por. Koh 12, 12). W bezliku bowiem słów wiele też, oczywiście, musi być grzechów. Bo: «W wielomówności nie obejdzie się bez grzechu» (Prz 10, 19)"²1.

Kapadocczyk miał początkowo pewne trudności, aby zdefiniować nowy błąd doktrynalny i chciał go zdyskredytować podporządkowując go zasadom dawnych herezji. Biskup Cezarei korzystał z argumentów długiej polemiki przeciwko doketom i gnostykom, ukazując, że Słowo przyjęło realne ciało ludzkie ${ }^{22}$. Z tą świadomością nie obawia się ukazywać paradoksalnych

${ }^{18}$ Chrystus w ujęciu Apolinarego, ponieważ jest jedną osobą, ma także jedną naturę: „Ona nie dzieli się na dwoje, ponieważ ani ciało nie jest jedną osobną naturą, ani też bóstwo nie jest oddzielną naturą we wcieleniu. Jako człowiek także Chrystus, który stał się podobny do ludzi, jest jedną naturą" (Apollinarius, Epistula ad Dionysium I 2, ed. Lietzmann, w: Apollinaris von Laodicea, s. 257, tłum. własne).

${ }^{19}$ Por. L. Perrone, „Four Gospels, Four Councils” - One Lord Jesus Christ. The Patristic Developments of Christology within the Church of Palestine, „Liber Annuus Studii Biblici Francescani" 49 (1999) 372.

${ }^{20}$ Basilius Caesariensis, Epistula 265, 2, ed. Courtonne, III, s. 129, thum. własne.

${ }^{21}$ Tenże, Epistula 263, 4, ed. Courtonne, III, s. 124, tłum. Krzyżaniak, s. 331.

${ }^{22}$ Por. tenże, De Spiritu Sancto V 12, 1-30, éd. B. Pruche, SCh 17bis, Paris 1968, 282-285, thum. A. Brzóstkowska: Św. Bazyli Wielki, O Duchu Świętym, wstęp J. Naumowicz, Warszawa 1999, 9596. Antydoketystyczny wydźwięk miało wyznanie wiary zredagowane przez Bazylego i podpisane przez Eustacjusza z Sebaste: „Wierzymy [...] w jednego Pana, Jezusa Chrystusa, Syna Bożego, Jednorodzonego [...], który dla nas ludzi i dla naszego zbawienia zstapił [na ziemię] i przybrał ciało; stał się człowiekiem, cierpiał, trzeciego dnia zmartwychwstał, wstapił na niebiosa, który ponownie przyjdzie sądzić żywych i umarłych [...]. Odnośnie do tych, którzy [...] uważają, że Syn Boży podlega zmianom czy odmianie, tych wszystkich Kościół katolicki i apostolski piętnuje anatemą" (tenże, Epistula 125, 2, ed. Courtonne, II, s. 32-33, tłum. Krzyżaniak, s. 155-156). 
aspektów wcielenia, mówiąc iż poprzez swoje cierpienie Zbawiciel uwolnił ludzi od cierpienia ${ }^{23}$.

Herezja apolinarystów była bardziej wyrafinowana niż dawne błędne nauki i nie wystarczało tylko jej odrzucenie i twierdzenie, że nie zasługiwała na uwage ${ }^{24}$. Przywołanie gnozy przez Bazylego wydaje się kluczowe. To „dawno już przebrzmiały pogląd Walentyna [...]. [To on] wyrwawszy kilka wypowiedzi Apostoła, ukuł na swój użytek wymysł bezecny. Orzekł on mianowicie u Chrystusa formę niewolną, a nie, że przybrał On postać niewolnika, i orzekł ponadto, że Pan zrodził się tylko na podobieństwo człowieka, ale postaci człowieka nie przybrał. Pewni ludzie u was rozgłaszają właśnie poglądy do tych podobne"25.

Bazyli wyczuł niebezpieczeństwo związane ze spekulacjami na temat wcielenia w prologu De fide i w niektórych homiliach. W tych tekstach Kapadocczyk przeciwstawiał się jeszcze niektórym tezom ariańskim ${ }^{26}$, lecz wzmiankował, choć nie expressis verbis, dyskusyjne wątki apolinaryzmu. Bazyli był oskarżony nie tylko od tryteizm, ale także o nierozróżnianie Osób Boskich i modalizm. Anonimowe pismo, wypowiadające się w tym duchu, wielu przypisywało Kapadocczykowi. On sam, rzecz jasna, chciał oddalić tego typu podejrzenia od siebie i zdemaskować heretyków. Podejrzenie padło jednak na Apolinarego, który miał sprzyjać tezom zbliżonym do błędu Sabeliusza ${ }^{27}$. Na prośbę Bazylego o wyjaśnienia Laodycejczyk odpowiedział dwukrotnie: jedną z odpowiedzi zawiera Epistula 362. w zbiorze korespondencji biskupa Cezarei ${ }^{28}$, a druga to tzw. Epistula Sebastiani ${ }^{29}$, która znalazła się w rękach Eustacjusza z Sebaste. Jednak Kapadocczyk oprócz tego, że musiał stawić czoła krańcowym opiniom arian, dostrzegł w pewnym momencie, że to błąd apolinarystów zaczął stanowić większe zagrożenie. Jego refleksja egzegetyczna i teologiczna miała wskazać na pełne człowieczeństwo Zbawiciela. Tego typu wątki znajdujemy w korespondencji bazyliańskiej ${ }^{30}$. To właśnie tam, obok problemów konkretnych osób i wspólnot, pojawiają się wątki dotyczące kontrowersji doktrynalnych.

${ }^{23}$ Por. tenże, De Spiritu Sancto VIII 18, 17-19, SCh 17bis, 308, tłum. Brzóstkowska, s. 106.

${ }^{24}$ Por. tenże, Epistula 263, 4, ed. Courtonne, III, s. 125, tłum. Krzyżaniak, s. 331: „Pisma [Apolinarego] o Wcieleniu taki zamęt spowodowały wśród wspólnoty braterskiej, że odtąd niewielu tylko z tych, którzy się z nimi spotkali, zachowało cechy dawnej pobożności, a większość, nastawiając uszu na nowinkarstwo, zeszła z właściwej drogi, aby zgłębiać i zuchwale wynajdywać te bezużyteczne wypowiedzi”.

${ }^{25}$ Tenże, Epistula 261, 2, ed. Courtonne, III, s. 117, tłum. Krzyżaniak, s. 324.

${ }^{26}$ Kazanie De fide należy uważać za swego rodzaju kompendium doktryny wyrażonej w sposób bardziej szczegółowy przez Bazylego w Adversus Eunomium.

${ }^{27}$ Por. tenże, Epistula 129, 1, ed. Courtonne, II, s. 39-40. W tym Liście, napisanym w 373 r., Kapadocczyk po raz pierwszy łączy z imieniem Apolinarego kwestię sabeliańską. Duet Apolinary Sabeliusz pojawia się w Liście 224 i 265.

${ }^{28}$ Ed. Courtonne, III, s. 222-224.

${ }^{29}$ Nazwana tak od nowożytnego wydawcy. Por. V.H. Drecoll, Die Entwicklung der Trinitätslehre des Basilius von Cäsarea. Sein Weg vom Homöusianer zum Neonizäner, Forschungen zur Kirchen und Dogmengeschichte 66, Göttingen 1996, 29-31.

${ }^{30}$ Por. Capone, Apollinaris, Basil and Gregory of Nyssa, s. 316. 
2. Filozoficzne podwaliny sporu. W polemice z błędnowiercami nie przebierano w środkach, a sztuka oratorska odgrywała w tym kontekście znaczną rolę. Heretycy byli zwykle przedstawiani w najczarniejszych barwach ${ }^{31}$. Nie ustrzegł się tego sam Bazyli, gdy wzmiankował apolinarystów. Topos literacki stanowiło posądzenie o brak rozsądku i brak zrozumienia w kwestiach wiary. Kapadocczyk wskazywał, że tezy apolinarystów cechowały się „,nieporadnością przemyśleń”, a z drugiej strony ,zobojętnienie wobec prawd objawionych odbiera nam możność wypowiadania się o Chrystusie"32.

Podobnie jak inne herezje apolinaryzm jest określany jako wprowadzanie innowacji ,przeciwko dogmatowi apostolskiemu”33. Owo nowinkarstwo ,sieje niepokój we wspólnocie braterskiej" ${ }^{34}$. Nie jest to nowy wątek, ale sięga do mentalności późnoantycznych filozofów, którzy byli przede wszystkim komentatorami dawnych tekstów. Istniało przekonanie, że prawdziwi myśliciele są ze sobą zgodni i że w ich refleksjach istnieje harmonia. Zadaniem komentatora tekstu filozoficznego było ukazanie owej zgodności ${ }^{35}$. Nawet, gdy pojawiały się rozbieżności, doświadczony erudyta dostrzegał, że są one powierzchowne, a w istocie poglądy współbrzmią w swoich treściach ${ }^{36}$. Odrzucano tylko absurdalne teorie, tak samo jak i nieuzasadnione nowości. Dla Bazylego pierwszorzędne znaczenie miała Tradycja Kościoła, do której nawiązywali Atanazy i zwolennicy prawowierności nicejskiej. Wraz z argumentami z Tradycji wzrastał również autorytet tekstów natchnionych. Jednakże specyficzny element metodologii filozoficznej miał swoją wagę i znaczenie.

W dyskusji o charakterze merytorycznym pojawiały się tego typu argumenty. Nie tylko Bazyli Wielki, ale także inni polemiści zakładali, że apolinaryści w sposób bezkrytyczny wprowadzali spekulacje filozoficzne do teologii. Głównie chodziło o rozróżnienia i podziały typu neoplatońskiego ${ }^{37}$. Jak wiadomo, dla Kapadocczyka droga wyłącznie racjonalna była niewystarczająca, bowiem pierwszeństwo miały treści wywodzące się bezpośrednio z objawienia

${ }^{31}$ Polemiści pierwszych wieków nie odróżniali osoby heretyka od głoszonego przez niego błędu. Tak więc na podstawie głoszonej herezji przypisywali i samym heretykom najgorsze przywary ludzkie. Eunomiusz zostaje przedstawiony jako „kłamliwy, ignorant, gwałtowny, małostkowy i bluźnierca" (Basilius Caesariensis, Adversus Eunomium I 1, éd. B. Sesboüé - G.-M. de Durand - L. Doutreleau, SCh 299, Paris 1982, 146-147, tłum. własne).

${ }^{32}$ Por. tenże, Epistula 262, 2, ed. Courtonne, III, s. 120, tłum. Krzyżaniak, s. 327.

${ }^{33}$ Tenże, Epistula 265, 2, ed. Courtonne, III, s. 128, tłum. własne.

${ }^{34}$ Tenże, Epistula 261, 1, ed. Courtonne, III, s. 115, tłum. Krzyżaniak, s. 323.

${ }^{35}$ Por. Simplicius, In Aristotelis Categorias commentarium $2^{\mathrm{r}} 55-2^{\mathrm{v}} 8$, ed. C. Kalbfleisch, w: Simplicius, Commentaria in Aristotelem Graeca, vol. 8, Berolini 1907, 23-32.

${ }^{36}$ W sposób szczególny zbieżność ta dotyczyła prawd wyrażonych przez Platona, który „tłumaczył prawdę", por. Simplicius, In Aristotelis De caelo commentaria 60a 14, ed. I.L. Heiberg, w: Simplicius, Commentaria in Aristotelem Graeca, vol. 7, Berolini 1894, 131, 1.

${ }^{37}$ Por. A. Tuilier, Le sens de l'Apollinarisme dans les controverses théologiques du It siècle, StPatr 13 (1975) 305; H.A. Wolfson, Philosophical Implications of Arianism and Apollinarianism, DOP 12 (1958) 3-28. 
biblijnego. Biskup Kapadocji przedstawił jednak doktrynę Boskiej substancji w sposób bardziej filozoficzny. Zastąpił określenie używane przez Apolinare-

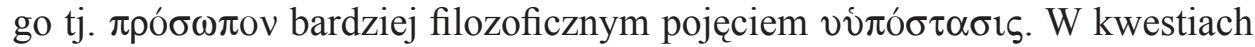
chrystologicznych zasady filozoficzne miały jednak ograniczone zastosowanie.

W homilii In Christi generationem ma się wrażenie, że w swojej refleksji Bazyli Wielki przeniósł problem judaistyczno-hellenistyczny dotyczący niezmienności Boga i wolności od zmysłowych reakcji ${ }^{38}$, na osobę Logosu. Ta zasada, która okazała się niezwykle pomocna w polemice antyapolinarystycznej, bazowała na formacji intelektualnej naszego autora ${ }^{39}$. Można doszukać

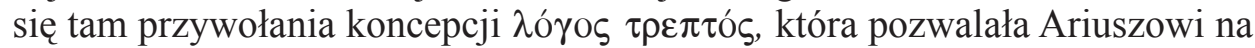
przypisywanie Słowu odruchów i ludzkich uczuć wspomnianych w Ewangelii. W ten sposób heretyk i jego późniejsi zwolennicy mogli zakładać niższy poziom bóstwa w Synu, różniącym się pod tym względem od Ojca. Kapadocczyk odrzuca jednak każdy typ takiej insynuacji. Wyjaśniał niestrudzenie, że

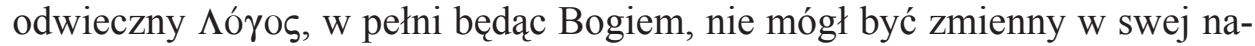
turze, jak byty stworzone. Bazyli dał przy tym jasną wykładnię rzeczywistości i natury prób, które dotknęły Chrystusa w Jego ziemskim życiu. To Zbawiciel przyjął na siebie naturalną $\pi \alpha ́ \theta \eta$, która jest niezbędną częścią trwania ludzkiej istoty, ukazując w ten sposób rzeczywistość swego wcielenia.

Apolinary miał świadomość, że jedność w Jezusie Chrystusie wykracza poza pobieżne i uproszczone pojmowanie zamieszkiwania Boga w człowieku. Fakt, iż odwieczne Słowo staje się rzeczywiście ciałem, oznacza, że bóstwo i człowieczeństwo wchodzą w istotową jedność. Tu jednak biskup z Laodycei natrafił na niełatwy do rozwikłania problem, filozoficzny i teologiczny zarazem, który miał też charakter metafizyczny i był związany z konstytucją bytu Jezusa Chrystusa. Nawiązując do słynnego filozoficznego aksjomatu, iż dwa doskonałe, kompletne byty nie mogą stać się jednym, Apolinary zastanawia się nad bytową strukturą Boga - Człowieka. Dwa podmioty - prawdziwy Bóg i prawdziwy człowiek - nie mogą stanowić ontologicznej jedności. Nie do pomyślenia jest współistnienie pełni bóstwa z pełnią człowieczeństwa w jednym bycie. Gdyby Bóg zjednoczył się z człowiekiem, nieskończenie doskonały z bytem cielesnym, to w efekcie istniałyby dwa podmioty: odwieczny Syn Boży i człowiek - Jezus. Trudno byłoby więc mówić o prawdziwym wcieleniu, a tym samym o jedności ${ }^{40}$. Apolinary głosił te tezy przywołując niektóre wyrażenia biblijne. „Każdy człowiek jest ziemski” - wyjaśniał Laodycejczyk.

${ }^{38}$ Ta prawda miała swój fundament w Biblii, co uzasadnia przywołana homilia. Por. Basilius Caesariensis, Homilia in sanctam Christi generationem 2, PG 31, 1460B - 1461C.

${ }^{39}$ Por. Plato, Respublica II 20, 381 B-C, ed. C.F. Hermann, Lipsiae 1911, 63, thum. W. Witwicki: Platon, Państwo, t. 1, Warszawa 1958, 126-127; Philo Alexandrinus, De Cherubim VI 18-20, ed. F.H. Colson and G.H. Whitaker, w: Philo, [Works], with an English translation, vol. 2, LCL 227, Cambridge MA - London 1958, 18-20.

${ }^{40}$ Jest to argument przeciwko modalistom oraz Pawłowi z Samosaty, mówiących o dwóch podmiotach w Chrystusie. 
„Chrystus nie jest «ziemski», lecz «niebiański». Tak więc już nie jest człowiekiem, jeśli pod określeniem człowiek nie rozumie się tej samej rzeczywistości niebiańskiej. Jeśli natura Chrystusa jest jak nasza, On jest «starym człowiekiem» i «duszą żyjącą», czyli nie duchem ożywiającym. Człowiek uczyniony w ten sposób nie daje życia. Chrystus jednak ożywia i jest duchem ożywicielem [...]. Tak więc nie jest takiej samej natury [jak] nasza"41.

Chociaż Apolinary negował obecność duszy racjonalnej w osobie Chrystusa, podkreślał jednak jedność pomiędzy Bogiem i człowiekiem, według zasady ,jedna natura wcielonego Logosu”. Podobnie jak inni Ojcowie Kościoła także i on, idąc śladem antycznych filozofów, rozróżniał popędy duszy i ciała.

Dla Bazylego konieczne odruchy ludzkie Pana ${ }^{42}$ były utrzymywane według miary i określonej granicy ${ }^{43}$. Mówi się o „,cierpieniach ciała [...] ożywionego", jak i doznaniach duszy w postaci ,smutków, niepokojów [...], trosk i wszelkich innych tego rodzaju uczuć" ${ }^{44}$. Kapadocczyk powtarzał za Orygenesem prawdę o „duszy posługującej się ciałem”" ${ }^{45}$. Było to pójście śladem starożytnych myślicieli, którzy na czele z Platonem, rozróżniali odruchy ciała i duszy ${ }^{46}$.

Przemyślenia filozofów odnoszące się do antropologii są wykorzystywane w lekturze tekstów biblijnych. W przypadku, gdy u Bazylego brak zainteresowań polemicznych, uczucia i ludzkie reakcje Chrystusa były rozpatrywane jako przykłady dla ludzi i nauka dla nich (aspekt dydaktyczny). Dotyczą tego opisy płaczu Jezusa czy Jego wzruszenia.

„Do tego, co dotyczy faktu, iż Pan opłakiwał Łazarza (por. J 11, 35), płakał nad miastem [świętym] (por. Łk 19,41) powinniśmy dopowiedzieć: On także jadł i pił. Nie dlatego, iżby tego potrzebował, ale aby pozostawić tobie miarę i granicę koniecznych odruchów duszy"47.

${ }^{41}$ Apollinarius, Recapitulatio (Anakephalaiosis) 23, ed. Lietzmann, s. 244-245, tłum. własne.

${ }^{42}$ Epifaniusz z Salaminy rozróżnia obecność „dobrych” albo „rozumnych” odruchów oraz „nierozumnych”. Po tym wyjaśnienie biskup Salaminy mógł stwierdzić, że Słowo, stając się ciałem, przyjęło tylko naturalne odruchy. W rzeczywistości „rozumny głód, pragnienie, zmęczenie [...], sen, smutek, płacz i trwoga" (Epiphanius, Panarion III 77, 26, 1-4, GCS 37, 438, 25 - 439, 22, thum. własne).

${ }^{43}$ Por. Basilius Caesariensis, Homilia IV: De gratiarum actione 5, PG 31, 228B-229B. Bazyli dostrzega w postępowaniu Chrystusa zasadę umiaru. Sformułował ją w odniesieniu do życia chrześcijan Klemens Aleksandryjski (Paedagogus II 1, 5, 1-4, ed. O. Stählin - U. Treu, GCS 12, Berlin 1972, 156, 27 - 157, 14, tłum. M. Szarmach: Klemens Aleksandryjski, Wychowawca, Toruń 2012, 85-86).

${ }^{44}$ Basilius Caesariensis, Epistula 261, 3, ed. Courtonne, III, s. 117, thum. Krzyżaniak, s. 323 i 325.

${ }^{45}$ Tamże, tłum. Krzyżaniak, s. 324. Por. Origenes, Contra Celsum VII 38, ed. P. Koetschau, GCS 3, Leipzig 1899, 188, 24, thum. S. Kalinkowski: Orygenes, Przeciw Celsusowi, PSP 17/2, Warszawa 1977, 178; tenże, De principiis IV 2, 7, 223-224, éd. H. Crouzel - M. Simonetti, SCh 268, Paris 1980, s. 328, tłum. S. Kalinkowski: Orygenes, O zasadach, PSP 23, Warszawa 1979, 307. Por. nota 49.

${ }^{46}$ Por. A. Vögtle, Affekt, RACh I 162 i 167.

${ }^{47}$ Basilius Caesariensis, Homilia IV: De gratiarum actione 5, PG 31, 228B, thum. własne. 
Bazyli miał jasno określoną wizję antropologiczną, lecz wyłożył ją w sposób jasny i systematyczne dopiero w swoich listach chrystologicznych. Kapadocczyk uważał, że nie każdy odruch lub popęd jest prawdziwie ludzki. Staje się takowym, gdy dotyczy duszy. W przeciwnym razie należy mówić o odruchach wyłącznie cielesnych.

„Czym innym są doznania ciała w ogóle, czym innym doznania ciała ożywionego, a czym innym wreszcie doznania duszy posługującej się ciałem ${ }^{48}$. Cechą swoistą ciała w ogóle jest to, że można je pociąć, zmiażdżyć i rozerwać, ciała natomiast ożywionego, że doznaje utrudzenia i bólu, odczuwa głód i pragnienie i daje się zmorzyć snem, gdy natomiast cechą swoistą duszy, posługującej się ciałem ${ }^{49}$, jest doznawanie smutków, niepokojów i trosk, i wszelkich innych tego rodzaju uczuć. Jedne z nich są naturalne i od żywej istoty nieodłączne, inne natomiast biorą się z niegodziwego wyboru i sadowią się obok pierwszych w następstwie życia nieuporządkowanego i niezaprawionego w cnocie" 50 .

Refleksje Kapadocczyka były nie tylko teoretyczne. Sięgnął on także po niektóre elementy ówczesnej wiedzy medycznej. Tego typu odnośniki okazywały się bardzo przydatne w nauczaniu moralnym ${ }^{51}$, ale także w polemikach. „Pan przyjął głód, gdy [z organizmu] zniknął pokarm stały i przyjął pragnienie, gdy został zużyty płynny humor w ciele ${ }^{52}$, jak również zmęczył się, gdyż z powodu chodzenia zbytnio były napięte mięśnie i nerwy"53.

Mówiąc o uczuciach naturalnych i koniecznych biskup Cezarei zdystansował się od twierdzeń Epifaniusza z Salaminy, który wyróżnił w człowieku obecność dobrych (racjonalnych) odruchów i nierozumnych pobudek. Tylko rozumne odruchy są dobre i godne człowieka. Kapadocki polemista nie oceniał odruchów pod względem racjonalnym, lecz etycznym. Terminologia bazyliańska odnosiła się do zasad Epikteta. Z kolei język pojęciowy Epifaniusza był bliski określeniom stoickim Zenona i Chryzypa. Ten ostatni, przyjmując teorie

${ }^{48}$ To Arystoteles dostrzegał w naturze racjonalność i harmonię: od ciał nieożywionych przechodzi się do ożywionych ciał organicznych (rośliny i zwierzęta) i wreszcie do obdarzonego myślącą duszą ciała człowieka.

${ }^{49}$ Bazyli przywołuje Orygenesową definicję człowieka jako „duszy posługującej się ciałem” (tenże, Contra Celsum VII 38, GCS 3, 188, 24, PSP 17/2, 178). Zob. także: tenże, De principiis IV 2 , 7, 223-224, SCh 268, 328, PSP 23, 307. Por. nota 45.

${ }^{50}$ Basilius Caesariensis, Epistula 261, 3, ed. Courtonne, III, s. 117-118, tłum. Krzyżaniak, s. 324-325. Bazyli ostrzega, że szatan wykorzystuje ,wrodzone skłonności natury albo zakazane namiętności” (tenże, Regulae brevius tractatae 75, PG 31, 1136A, thum. J. Naumowicz, w: Bazyli Wielki, Pisma ascetyczne, ŹM 6, Kraków - Tyniec 2011², 300).

${ }^{51}$ Niektóre przykłady w: tenże, Homilia IX: Quod Deus non est factor malorum 3, PG 31, 333B-C; tenże, Regulae fusius tractatae 55, 2, PG 31, 1120B.

${ }^{52}$ To Galen, opierając się na nauce Hippokratesa i Arystotelesa, propagował w medycynie koncepcję humoralną.

${ }^{53}$ Tenże, Homilia IV: De gratiarum actione 5, PG 31, 228C-D, thum. własne. 
Zenona i przeciwstawiając się założeniom akademicko-patetycznym, definiuje pragnienie jako nierozumne. Określenie to jest obecne u Arystotelesa ${ }^{54}$.

Dla Bazylego dobro i zło opierają się na wyborze racjonalnej istoty, a ocena moralna uczuć jest decydująca. Idąc śladami Epikteta ${ }^{55}$ biskup Cezarei Kapadockiej przeciwstawia się hipotezie apolinarystycznej, dostrzegającej w ludzkiej naturze coś wyłącznie zmiennego, więc grzesznego. Tak więc zjednoczenie Logosu z ludzkim ciałem dla Laodycejczyka mogło nastąpić tylko na poziomie fizycznym, wyłączając możliwości woli ludzkiej w osobie Zbawiciela.

„Pan miewał doznania naturalne dla potwierdzenia swego prawdziwego, a nie tylko pozornego wcielenia się w człowieka, ale wszelkie doznania grzeszne, brukające czystość naszego życia, odrzucił On od siebie jako niegodne Jego nieskażonego Bóstwa. Dlatego orzeka się, że narodził się On «w podobieństwie ciała grzesznego» $(\mathrm{Rz} 8,3)^{\prime \prime 56}$.

Apolinary manipulował przywołanym tekstem Rz 8, 3. W oparciu o terminologię biblijną (,podobieństwo”) negował rzeczywiste i doskonałe człowieczeństwo w Chrystusie. Bazyli postawił pod pręgierzem swojej krytyki także kolejna, nieuniknioną konsekwencję kwestionowanego systemu chrystologicznego. Kiedy zostało zredukowane człowieczeństwo Chrystusa, apolinaryzm, który nie odróżniał elementu etycznego i konstytutywnego, siłą rzeczy musiał odnieść ludzkie popędy także do podmiotu Boskiego. Tylko poprzez rozróżnienie elementów konstytutywnego i moralnego można uniknąć odniesienia do boskości Chrystusa negatywnych uczuć. Jednocześnie Kapadocczyk z całą konsekwencją uznaje obecność ludzkich odruchów w Chrystusie, które są integralną częścią natury każdej osoby ludzkiej. Poprzez te uściślenia Bazyli sprzeciwia się niektórym tezom Apolinarego, które zostały przytoczone przez Grzegorza z Nyssy ${ }^{57}$.

Kapadocczyk kontynuuje: ,[Chrystus] przybrał wprawdzie nasze ludzkie ciało wraz z jego naturalnymi doznaniami, ale grzechu żadnego nie popełnił (por. 1P 2, 22)" ${ }^{58}$. Nie można wykluczać wpływu Plotyna, który mówił o duszy posługującej się ciałem i odruchach cielesnych ${ }^{59}$. Pomimo znacznego wpływu,

\footnotetext{
${ }^{54}$ Por. Aristoteles, Ars Rhetorica I 10, 1369a 2-7. Zob. Chrysippus, Vitae agendae praecepta, fragm. 768, SVF I 191. Inne pouczenia tego typu tamże, s. 194 i 196.

${ }^{55} \mathrm{~W}$ ludzkiej mocy jest wybór dobra lub zła, pragnienia i popędy. Por. Epictetus, Diatriba II 16, ed. W.A. Oldfather, I, LCL 131, Cambridge MA - London, 1959, 320-336, thum. L. Joachimowicz: Epiktet, Diatryby, Warszawa 1961, 155-162. Zob. A.A. Long, A Stoic and Socratic Guide to Life, Oxford 2002, 220-223.

${ }^{56}$ Basilius Caesariensis, Epistula 261, 3, ed. Courtonne, III, s. 118, thum. Krzyżaniak, s. 325.

${ }^{57}$ Por. Apollinare, Epifanio, Gregorio Nazianzeno, Gregorio di Nissa e altri su Cristo. Il grande dibattito nel quarto secolo, testi originali, introduzione, note e traduzione a cura di E. Bellini, Di Fronte e Attraverso 35, Milano 1978, 480.

${ }^{58}$ Basilius Caesariensis, Epistula 261, 3, ed. Courtonne, III, s. 118, thum. Krzyżaniak, s. 325.

${ }^{59}$ Por. Plotinus, Enneades I 1, 3, ed. R. Volkmann, vol. 1, Lipsiae 1883, 40-41, thum. A. Krokiewicz: Plotyn, Enneady, t. 1, Warszawa 2000, 91-92.
} 
jaki wywarła myśl plotyńska na wczesne chrześcijaństwo, należy podkreślić fakt, iż Plotyn odrzucił naukę o możliwości wcielenia Boga ${ }^{60}$. Kapadocczyk na pierwszym miejscu odwołuje się do nauki Pisma Świętego, którego nie można stawiać na równi z dziełami filozofów, ponieważ każda stronica Biblii została napisana „dla zbudowania i zbawienia dusz" ${ }^{61}$. Według Bazylego natchniony tekst, w konkretnym przypadku Rz 8, 3, wyraża się w taki sposób, nie dlatego aby definiować strukturę ontologiczną Chrystusa, ale by ukazać brak w Nim wszelkiego grzechu, jak to przypomina 1P 2, 22.

$\mathrm{Na}$ potrzeby polemiki antyapolinarystycznej Bazyli dokonał dokładnego i elementarnego rozróżnienia pomiędzy różnymi odruchami. Odwieczne Słowo nie podlegające cierpieniu ${ }^{62}$, przyjęło odruchy związane z ograniczonością ludzkiej natury. Tak więc, ,kto orzeka, że ludzkie cierpienia przenoszą się zarazem na samą Boską naturę, postępuje obyczajem tych, którzy nie uchowali w sobie szczypty poprawnego rozumowania" ${ }^{63}$. Co prawda Chryzyp głosił, że z powodu zaburzeń funkcjonowania ciała (czyli cierpienia), nawet mędrzec może utracić wewnętrzną równowagę ${ }^{64}$, to przenoszenie tej zasady na naturę boską było w najwyższym stopnie niedorzeczne. Prostując podobnego typu błędy Bazyli wskazał, że „ludzkie ciało Pana stało się uczestnikiem bóstwa, ale nie uczyniło [Go] uczestnikiem właściwej [ciału] słabości" ${ }^{65}$.

Bazyli wskazuje ponadto na dobroć ludzkiej natury. Ta pozytywna perspektywa rozważań pozwala na skonstatowanie, że natura człowieka otrzymała od Boga zdolność, aby kierować się ku dobru. Ono jest jej fundamentem.

„Gdy chcemy, nie jest trudno umiłować sprawiedliwości znienawidzić nieprawości ${ }^{66}$. Bóg bowiem dał wszelką pomoc na korzyść duszy rozumnej, zarówno możliwość miłości jak i nienawiści, abyśmy kierowani przez rozum miłowali cnotę i nienawidzili zła" ${ }^{67}$.

\section{Z przekonaniem biskup Cezarei mówił ponadto:}

„Wraz z kształtowaniem się istoty żyjącej (chodzi o człowieka) została wszczepiona jakaś moc zarodkowa, zawierająca w sobie zdolność i skłonność do mi-

${ }^{60}$ Por. tamże III 6, 6, ed. Volkmann, vol. 1, s. 288-291, tłum. Krokiewicz, s. 307-310. Zob. G. Reale, Historia filozofii starożytnej, tłum. E. I. Zieliński, t. 4, Lublin 2005, 588.

${ }^{61}$ Basilius Caesariensis, Homiliae in Hexaemeron IX 1, éd. S. Giet, SCh 26bis, Paris 1968, 482, thum. własne.

${ }^{62} \mathrm{~W}$ myśl filozofii greckiej niepodleganie cierpieniu to jeden z najważniejszych przymiotów Boga. Na temat tej cechy Logosu por.tenże, Homilia XVI: In illud: „In principium erat Verbum” 3 , PG 31, 476C - 480A.

${ }^{63}$ Tenże, Epistula 261, 3, ed. Courtonne, III, s. 118, tłum. Krzyżaniak, s. 324.

${ }^{64}$ Por. T. Tielman, Chrisippus' On affections: Reconstruction and Interpretation, Boston 2003, 164-165.

${ }^{65}$ Basilius Caesariensis, Homilia in sanctam Christi generationem 2, PG 31, 1461 A, thum. własne.

${ }^{66}$ Nawiązanie do Ps 44, 8, którego egzegezą Bazyli się zajmował w cytowanej homilii.

${ }^{67}$ Tenże, Homilia in Psalmum XLIV 7-8, PG 29, 405B, thum. własne. 
łowania. Szkoła przykazań Bożych przyjmując to ziarno, troskliwie je uprawia, umiejętnie pielęgnuje i za łaską Bożą doprowadza do doskonałości”ø8.

To dowód typowo stoickiego optymizmu względem człowieka, który jest zdolny do dobra i praktykowania cnoty ${ }^{69}$. „To, co czynimy dobrze z wolnej woli, stanowi wrodzoną cechę naszej natury, jeśli tylko nie jesteśmy w naszych myślach zepsuci złem" "70. Dla biskupa-mnicha celem dążeń ludzkich jest wyłącznie Bóg ${ }^{71}$.

Sposobu rozumowania Apolinarego można zaledwie się domyślać. Laodycejczyk za punkt wyjścia przyjął koncepcje platońskie i elementy antropologii biblijnej. Wcielony Syn Boży ma ludzkie ciało ( $\sigma \alpha ́ \rho \xi)$ i duszę zmysłowa ( $\psi v \chi \eta ́)$, nie przyjął zaś duszy rozumnej (vov̂s), bo jej miejsce zajął w Nim $\Lambda$ ó $\mathrm{S}^{72}$. W oparciu o 1Tes 5, 23 nauczał, że Boskie Słowo zastąpiło w Chrystusie normalną, ludzką sferę psychiczną. Rolę, jaką w każdym innym człowieku spełnia rozumna i wolna ludzka dusza (vov̂s), przejmuje w Nim boski Duch $(\pi v \varepsilon \hat{v} \mu \alpha)^{73}$. Dyskutuje się, czy Apolinary był dychotomistą, uznającym, że ludzka natura składa się z ciała i duszy, czy też trychotomistą, przekonanym, że tworzą ją ciało, dusza zmysłowa i dusza rozumna ${ }^{74}$. Być może pod wpływem narastającej krytyki ze strony przedstawicieli nurtu antiocheńskiego w teologii, dokonał pewnej korekty koncepcji dychotomicznej, próbując rozwiązać problem jedności za pomocą platońskiej trychotomii. W myśl tej trychotomicznej koncepcji wcielone Słowo, zachowując duszę zmysłową, byłoby pozbawione duszy rozumnej. Obydwie koncepcje są zgodne w zanegowaniu w Chrystusie najwyższego elementu ludzkiego bytu, zastąpionego

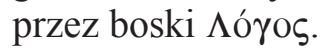

${ }^{68}$ Tenże, Regulae fusius tractatae 2, 1, PG 31, 908C, ŹM 6, 63.

${ }^{69}$ Por. M. Pohlenz, Die Stoa. Geschichte einer geistigen Bewegung, Göttingen 1992, 123.

${ }^{70}$ Basilius Caesariensis, Regulae fusius tractatae 2, 1, 2, PG 31, 912A, ŹM 6, 66.

${ }^{71}$ Por. tamże: „Z natury swej ludzie łakną rzeczy pięknych [...]. Godne miłości jest to, co dobre. I Bóg jest dobrem. Wszystko pożąda Dobra, wszystko więc pragnie Boga”. Grzegorz z Nyssy wyraża się podobnie. Zob. Gregorius Nyssenus, De instituto christiano, ed. W. Jaeger, GNO 8/1, Leiden 1952, 40, 1-9.

${ }^{72}$ Por. Kelly, Początki doktryny chrześcijańskiej, s. 219.

${ }^{73}$ Apolinaryści wprowadzali terminologię dotyczącą „ducha” w kontekstach egzegetycznych i sakramentalnych. Por. Basilio di Cesarea, Testi cristologici, a cura di G. Mazzanti, Cultura Cristiana Antica. Testi, Roma 1991, 80, nota. 16.

${ }^{74}$ Już apologeta Justyn (Apologia II 10, 3, ed. J.C.Th. Otto, w: Corpus Apologetarum Christianorum saeculi secundi, I/1, Wiesbaden 1969, 226, tłum. L. Misiarczyk: Justyn Męczennik, 2 Apologia, w: Justyn Męczennik, 1 i 2 Apologia. Dialog z Żydem Tryfonem, Warszawa 2012, 97) opisywał Chrystusa jako ciało, Logos i duszę. W tych niejasnych określeniach może chodzić o prawdziwość ludzkiej natury Zbawiciela (ciało i dusza) przy jednoczesnym wyodrębnieniu elementu utożsamianego z drugą z natur - Boską (Logos). Można się tu doszukać twierdzeń skierowanych przeciwko doketom, chociaż nie jest wykluczone, że apologecie chodzi przede wszystkim o podkreślenie ożywiającej mocy Chrystusa, gdyż słowo „dusza” jest synonimem ,życia”. Tak pojęty Logos osobowy i wcielony jest pośrednikiem stworzenia i objawienia oraz źródłem poznania prawdy. 
Trychotomia: duch, dusza i ciało w osobie Chrystusa miała według Apolinarego szczególną postać. Negowanie obecności duszy racjonalnej (vov̂s), oznaczało wykluczenie elementu implikującego wybór między dobrem a złem, a tym samym możliwość grzechu. Błędem Laodycejczyka było to, że nie potrafił rozróżnić pomiędzy płaszczyzną fizyczno-ontologiczną a tendencją do grzechu, która jest w człowieku. Ponadto w jego opinii skłonność do zła byłaby głęboko zakorzeniona w bycie ludzkim. W błędnej antropologii apolinarystycznej człowiek praktycznie identyfikuje się z własnym grzechem. Bazyli wykazuje podobną troskę jak Apolinary o wskazanie na bezgrzeszność Chrystusa. Konkluzja Kapadocczyka jest identyczna: Zbawiciel nie miał grzechu. Jednak motywacja była innego rodzaju: Chrystus był wolny od grzechu nie dlatego, iż nie był w pełni człowiekiem, ale dlatego, że nie wybrał grzechu ${ }^{75}$.

3. Egzegeza antyapolinarystyczna. Egzegeza Bazylego służyła temu, by przeciwstawić ekstremizm ontologiczny opinii Pisma Swiętego na temat pełnego bóstwa Chrystusa i wskazać na Jego pełne człowieczeństwo. Na tym skupiała się w wielu miejscach już refleksja w De fide. Została przedstawiona tam relacja Ojca do Syna: Bóg Ojciec jest początkiem Syna i z Niego został On zrodzony jako Moc, Mądrość i Obraz. Uderza przede wszystkim biblijność analizowanej homilii, która wydaje się niczym innym jak wyznaniem wiary. Bazyli wprowadza J 1, 1 i Ba 3, 38, harmonizując oba teksty tak, aby stanowi-

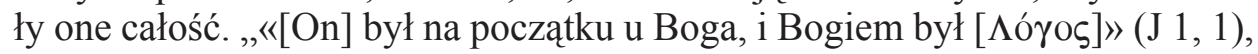
a «potem» według Pisma «ukazał się on na ziemi i zaczął przebywać wśród ludzi» $(\mathrm{Ba} 3,38)^{\prime \prime 76}$.

Dzięki J 1, 1 biskup Cezarei odwołuje się do preegzystencji Słowa, natomiast wcielenie zostaje przypomniane nie za pomocą $\mathrm{J} 1,14$ ale $\mathrm{Ba} 3,38^{77}$. Akcentując potem człowieczeństwo Zbawcy, Kapadocczyk cytuje Flp 2, 6. 8. Jednak zamiast wersetu 7 wprowadza wyrażenie ,przez narodzenie z Dziewicy", odwołując się tym samym do Ga $4,4^{78}$. Znaczenie tej operacji egzegetycznej staje się ewidentne, gdy bierze się pod uwagę fakt, że szkoła apolinarystyczna opierała się na J 1, 14 i Flp 2, $7^{79}$, by udowodnić, że Chrystus nie posiadał człowieczeństwa we wszystkim podobnego do naszego ${ }^{80}$.

${ }^{75}$ Do analogicznych konkluzji doszedł Sofroniusz z Jerozolimy (Epistula Synodica ad Sergium, PG 87/3, 3173C; Encomium in sanctum Joannem Baptistam 4, PG 87/3, 3328C).

${ }^{76}$ Basilius Caesariensis, De fide, PG 31, 685A, tłum. własne.

${ }^{77}$ Por. tenże, Homilia V: In martyrem Iulittam, PG 31, 253C, gdzie Bazyli łączy Ba 3, 38 i J 1, 14. Elena Cavalcanti błędnie twierdzi, że „Bazyli nigdy nie używa cytatu z Ba 3, 36-38” (taż, Osservazioni sull'uso di Baruch 3, 36-38, w: Mémorial Dom Jean Gribomont (1920-1986), SEA 27, Roma 1988, 155, nota 33.

${ }^{78}$ Por. Basilius Caesariensis, De fide, PG 31, 685A.

${ }^{79}$ Podobne zestawienie w: Basilius Caesariensis, Adversus Eunomium II 3, 1-30, éd. B. Sesboüé - G.-M. de Durand - L. Doutreleau, SCh 305, Paris 1983, 16-19.

${ }^{80}$ Por. Gregorius Nazianzenus, Epistula 102, 12, PG 37, 196A, thum. J. Stahr: Grzegorz z Nazjanzu. Listy, POK 15, Poznań 1933, 147. 
Sformułowania z Flp 2, 6-8 były bardzo wygodne dla apolinarystów i służyły jako podstawa dla chrystologii apolinarystycznej. Bazyli celowo pozostawia na uboczu wyrażenie Pawłowe, ponieważ mogło ono stać się pretekstem szerzenia wątpliwości na temat przybranego przez Chrystusa człowieczeństwa. To powód zamiennego użycia Ga 4, 4 .

Także w swojej korespondencji Kapadocczyk odbiera błędnowiercom argumenty biblijne. Swoją interpretację uczynił przekaźnikiem właściwej koncepcji chrystologicznej. Bazyli wskazuje na nieprawidłowości egzegezy apolinarystów i w tonie polemicznym wypowiada twierdzenia chrystologiczne

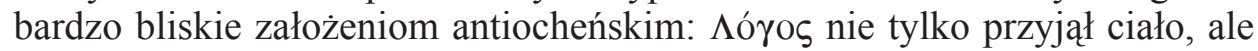
wziął na siebie całego człowieka ${ }^{81}$.

O znaczeniu tego typu wyjaśnień przekonuje sam Bazyli, gdy wspomina o pewnych błędnowiercach, którzy „nie ustają w sporach co do wcielenia Pana"82. Sam fakt konfliktów nie wydawał się w tym momencie kluczowy. O wiele większe znaczenie miały argumenty używane w tej kontrowersji. Ponadto dyskusje dotyczyły kwestii egzegetycznych, tak więc refleksja teologiczna nie bazowała wyłącznie na spekulacji intelektualnej, ale należało zaproponować alternatywną i ortodoksyjną interpretację tekstów biblijnych.

„Gdyby Bóg przeobraził się, to zarazem stałby się inny. Otóż byłoby niepodobieństwem tak orzekać i głosić, jako że Bóg powiedział: «Jam jest i nie odmieniam się» (Ml 3, 6). A dalej, jakaż to korzyść z wcielenia mogłaby przejść na nas, gdyby nasze ciało nie zespoliło się z bóstwem, które przezwyciężyło władztwo śmierci? Ten bowiem, który przemienił się, przybrał sobie własne ciało, istniejące razem ze skupionym w nim bóstwem. Jakże jednak nie dające się ogarnąc bóstwo mogłoby być sprowadzone do rozmiarów znikomego ciała, gdyby przemieniła się cała natura Jednorodzonego Syna Bożego? Otóż sądzę, że nikt, kto przy zdrowych zmysłach i kogo stać na bojaźń Boga, nie cierpi na takie zamroczenie" 83 .

Celem odparcia argumentów heretyckich dotyczących interpretacji wcielenia Logosu (por. J 1, 14), nasz autor za pomocą terminologii biblijnej, filozoficznej i ściśle teologicznej przywołuje ideę zbawczego przyjścia Chrystusa w ciele. Jako Bóg „,byłby bowiem niedosięgły z powodu wielkości swego bóstwa, gdyby nie uniżył się do fizycznej nędzy człowieka"84. Człowiek potrzebował Zbawcy, który przewyższałby jego naturę, czyli Boga-człowieka. Jest nim wcielony Syn Boży, który jako jedyny może ofiarować Ojcu zadośćuczynienie za wszystkich ${ }^{85}$.

\footnotetext{
${ }^{81}$ Por. Basilio di Cesarea, Testi cristologici, s. 101, nota. 9.

${ }^{82}$ Por. tenże, Epistula 260, 8, ed. Courtonne, III, s. 114-115, tłum. Krzyżaniak, s. 321.

${ }^{83}$ Por. tenże, Epistula 262, 2. ed. Courtonne, III, s. 120, tłum. Krzyżaniak, s. 327.

${ }^{84}$ Tenże, Homilia I: De ieiunio 9, PG 31, 177D, tłum. własne.

${ }^{85}$ Por. tenże, Homilia in Psalmum XLVIII 4, PG 29, 440B - 441C.
} 
Jednak oprócz bezwarunkowego przyjęcia prawdy o wcieleniu, należało ten dogmat wyjaśnić. Był on przecież podstawą wszelkiej refleksji chrystologicznej. Polemika antyheretycka odnosząca się do J 1, 14 spowodowała pewną ewolucję jeśli chodzi o egzegezę. Początkowo Kapadocczyk nie przywiązywał specjalnej wagi do jego interpretacji, ani zbyt często go nie przywoływał. Jednak z chwila, gdy pozycje apolinarystyczne zaczęły przybierać wyraźne kontury odstępstwa od wiary, biskup Cezarei stał się ostrożny, jeśli chodzi o użycie wyrażenia „Słowo stało się ciałem”. Bazyli zaczął cytować wersety Janowe już przetworzone egzegetycznie i teologicznie, zastępując słowo $\sigma \alpha ́ \rho \xi \xi$ określeniem ớv $\theta \rho \omega \pi \mathrm{o}^{86}$. Jednak polemizując z Apolinarym, nigdy nie zagłębiał się w problematykę związaną z pojęciem $\sigma \alpha ́ \rho \xi$, lecz preferował rozwiązywanie sedna problemu.

To pozwala na wskazanie, że Słowo przyjęło w całej pełni i ze wszystkimi konsekwencjami człowieczeństwo, nie tracąc jednak tego, co „należy do bóstwa" ${ }^{87}$. Stwierdzenie Janowe ujawnia się więc jako podstawowy element chrystologii. Chociaż sposób dowodzenia Bazylego wydaje się naginaniem tekstu biblijnego, to jednak było to postępowanie standardowe wśród ówczesnych egzegetów. Ze względu na kontrowersje wywołane przez zwolenników apolinaryzmu, Kapadocczyk systematycznie i konsekwentnie mówi o „stawaniu się człowiekiem", a nie wyłącznie o wcieleniu Logosu. Biskup Cezarei był świadomy faktu, że sformułowania Janowe mogły być wykorzystane z powodzeniem przez tych, którzy zaprzeczali skutkom przyjęcia człowieczeństwa

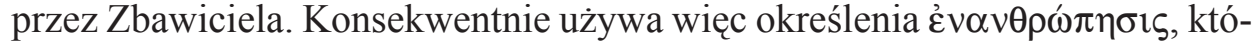
re wcześniej pojawiło się u Atanazego z Aleksandriii ${ }^{88}$.

Bazyli podąża śladem biskupa Aleksandrii, wskazując, że wcielenie Słowa oznacza w praktyce zjednoczenie Słowa z człowiekiem ${ }^{89}$. Ciało pojmowane jest jako cały człowiek ${ }^{90}$. W innych kontekstach $\sigma o ́ p \rho \xi$ jest miejscem i narzędziem

${ }^{86}$ Teodor z Mopsuestii ciagle podkreślał człowieczeństwo Chrystusa obok obecności boskiego Logosu w Jego osobie. Czyni przy tym tak wyraźnie rozróżnienie, że przedstawia jakby dwa oddzielne podmioty, które chociaż nierozłączne, są jednak jasno wyodrębnione. Por. M. Simonetti, Między dosłownościq a alegoriq. Przyczynek do historii egzegezy patrystycznej, thum. T. Skibiński, Myśl Teologiczna 26, Kraków 2000, 180.

${ }^{87}$ Basilius Caesariensis, Homilia XVI: In illud: „In principium erat Verbum” 3, PG 31, 477B, tłum. własne.

${ }^{88}$ Michał Wojciechowski proponuje polski odpowiednik „wczłowieczenie”, będący wierniejszym i głębszym określeniem niż „wcielenie”. Enathropesis oznacza stawanie się człowiekiem, a więc nie ogranicza się tylko do przyjęcia ludzkiego ciała, ale całej natury człowieka. Por. M. Wojciechowski, Wprowadzenie, w: Atanazy z Aleksandrii, O Wcieleniu Słowa, thum. M. Wojciechowski, PSP 61, Warszawa 1998, 14-15.

${ }^{89}$ Filon Aleksandryjski (De specialibus legibus III 36, 204, ed. Colson, vol. 7, LCL 320, Cambridge MA - London 1958, 599) mówił o Logosie, zamieszkującym ludzki intelekt, który stawał się nauczycielem rozumnego bytu.

${ }^{90}$ Logos, będący jednocześnie doskonałym i prawdziwym Bogiem, przyjmuje pełne człowieczeństwo do tego stopnia, że Jego ciało jest współistotne z ciałem człowieka. Por. P.M. Szew- 
objawienia się Boga. W liście do biskupów Paraplioris Bazyli zsyntetyzował kwestię wcielenia, mówiąc, że „Bóg zechciał żyć wśród nas w ciele”"91.

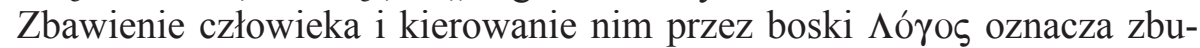
dowanie całkowicie nowej relacji ze stworzeniem, a wcielenie doprowadziło do zaistnienia ludzkiej natury w Logosie. Człowieczeństwo Logosu jest zupełnie nowe, nieśmiertelne i całkowicie wolne od zniszczalności ${ }^{92}$. Biskup Aleksandrii utożsamiał zwrot „,iało Logosu”93 z wyrażeniem ,człowiek Logosu". Ziemskie życie wcielonego Słowa było w pełni ludzkim życiem ${ }^{94}$, a jego głównym zamiarem było zbawienie ludzi. Słowo Boże „stało się człowiekiem, byśmy stali się Bogiem; On stał się widzialny w ciele, abyśmy mieli wyobrażenie o Ojcu niewidzialnym. [On] zniósł od ludzi przemoc, abyśmy odziedziczyli niezniszczalność" ${ }^{95}$. Tego typu sformułowania nie występują często u Kapadocczyka, chociaż tak wiele mówił on o wcieleniu i jego znaczeniu. Przy innej okazji wspominał natomiast o problemie niektórych wiernych zastanawiających się, ,w jaki sposób podległa zepsuciu natura [ludzka], dzięki swojemu zjednoczeniu z Bogiem, stała się niezniszczalna"96.

W Liście 261., dzięki przywołaniu Rz 5, 17 i 8, 3, pojawia się powód, by Bazyli mógł jednak nawiązać do fundamentalnej zasady soteriologicznej wyrażonej przez Atanazego. Odrzucenie jej w praktyce, tak jak w przypadku Apolinarego, prowadziło do zanegowania dzieła zbawczego. Laodycejczyk twierdząc, że przy wcieleniu Logos przyjął ciało niebieskie, wskazał na ciało odmienne niż ludzkie ${ }^{97}$. Mówiąc w ten sposób apolinaryzm wyrażał słuszną troskę, aby wykluczyć z osoby Chrystusa wszelki ślad grzechu ludzkiego, a więc także związków ze starym człowiekiem, grzesznym Adamem. Ponadto apolinaryści starali się pokazać, że zbawienie jest dziełem Boga, a nie człowieka.

Mimo najlepszych chęci Apolinary schodzi na bezdroża, ponieważ przez swoje supozycje odłącza Chrystusa i Jego dzieło od pełnego człowieczeństwa, które potrzebowało odkupienia. Kapadocczyk trzeźwo ocenia konsekwencje idei apolinarystycznych. Na sposób oratorski ukazuje dobrodziejstwa, których

czyk, Człowieczeństwo Logosu wedlug Atanazego Wielkiego, Myśl Teologiczna 65, Kraków 2010, 239-240.

${ }^{91}$ Basilius Caesariensis, Epistula 203, 1, ed. Courtonne, II, s. 167, thum. własne. Jest to synteza Ba 3, 38 i 1 Tm 3, 16. Wydawca wskazuje na J 1,14..

${ }_{92}$ Por. Szewczyk, Człowieczeństwo Logosu, s. 240-241.

${ }^{93}$ Atanazy pojmował „ciało” w sensie biblijnym jako fundament człowieczeństwa. Ono, dzięki wcielonemu Logosowi, wprowadza ,pokrewieństwo” z Bogiem, stąd całe człowieczeństwo zostaje przemienione.

${ }^{94}$ Por. Szewczyk, Człowieczeństwo Logosu, s. 234-236 i 242.

${ }^{95}$ Athanasius Alexandrinus, De incarnatione Verbi 54, 3, ed. Ch. Kannengiesser, SCh 199, Paris 1973, 458, thum. własne. Na temat tej formuły u Atanazego por. J. Naumowicz, Wcielenie Boga i zbawienie człowieka. Złota reguła soteriologii patrystycznej, WST 13 (2000) 23-25.

${ }^{96}$ Basilius Caesariensis, Homilia in sanctam Christi generationem 2, PG 31, 1461 A, thum. własne.

${ }^{97}$ Por. Grillmeier, Christ in Christian Tradition, s. 222-225. 
udziela Pan, a które nie miałyby prawa zaistnieć, gdyby supozycje heretyckie były prawdziwe. To powód, dla którego Bazyli przywołuje postać „Świętej Dziewicy [Maryi]”, by ukazać, że „,z Adamowej gliny miało być pobrane ciało, w którym Chrystus zagości" ${ }^{98}$. Rola Bożej Rodzicielki sprowadza się tutaj do zagwarantowania pełnego człowieczeństwa Chrystusa ${ }^{99}$.

Na potwierdzenie swych tez biskup z Laodycei odwoływał się do 1Kor 15, 45. Dodatkowe biblijne oparcie dla swojej tezy dostrzegł również we fragmencie Janowego prologu: „Słowo stało się ciałem” (J 1, 14), gdzie użyte zostaje greckie pojęcie $\sigma \alpha ́ \rho \xi$. Interpretacja 1Kor 15, 54 ze strony Apolinarego jest problematyczna. Stąd kolejny ważny przyczynek w korespondencji Bazylego:

„Podobnie [...], jak śmiertelność co do ciała przekazana nam przez Adama, zniweczona została przez bóstwo (por. 1Kor 15, 54), tak samo grzech rozproszony został przez sprawiedliwość, jaka jest w Jezusie Chrystusie, tak że przy zmartwychwstaniu odzyskamy nasze ciało, śmierci już nie podległe i grzechowi nie poddane" 100 .

Dzieło zbawcze Chrystusa dokonuje się przez działanie Jego boskości i człowieczeństwa. Człowiek przez grzech sprowadził na siebie śmierć na poziomie fizycznym i obumarł duchowo (poziom etyczny). Tylko bóstwo mogło dokonać zbawienia w sposób całkowity, zarówno na płaszczyźnie fizycznej, eliminując śmierć człowieka, jak i na płaszczyźnie moralnej, dokonując jego uświęcenia. Biskup Cezarei pozostaje wierny podwójnej perspektywie: fizycznej i etycznej, co ukazuje, że jego wizja antropologiczna łączy się z chrystologią. Dzieło zbawcze Syna sprawia, że człowiek powraca do swej integralności.

Na niektóre teologiczne obiekcje Bazyli odpowiada w homilii Adversus eos qui per calumniam dicunt dici a nobis tres deos esse $e^{101}$. Mowa ta ma charakter dogmatyczny, ponieważ Kapadocczyk chcąc uniknąć nieporozumień typu apolinarystycznego nie cytuje dosłownie J 1, 14 i niemalże z antiocheńskim wyczuleniem oświadcza:

„Słowo, Syn Boży ${ }^{102}$, stał się człowiekiem z powodu upadku człowieka Adama $^{103}$. Z powodu Adama, ten który jest bezcielesny, znalazł się w ciele. Słowo przyjęło ciało jak obłok, aby nie zniweczyć [w ogniu] rzeczy wi-

\footnotetext{
${ }^{98}$ Basilius Caesariensis, Epistula 261, 2, ed. Courtonne, III, s. 117, thum. Krzyżaniak, s. 324.

${ }^{99}$ Przy innych okazjach Bazyli (Homilia in sanctam Christi generationem 3, PG 31, 1461C - 1464D) uważa obecność Maryi jako kluczową w dziele zbawienia, by zapewnić bezgrzeszne ciało dla Syna.

${ }^{100}$ Tenże, Epistula 261, 3, ed. Courtonne, III, s. 118, thum. Krzyżaniak, s. 325.

${ }^{101}$ Por. tenże, Homilia adversus eos qui per calumniam dicunt dici a nobis tres deos esse 4, PG 31, 1493C - 1496A.

${ }^{102}$ Bazyli łączy tu dwa określenia, które w innym miejscu uważa za komplementarne. Homilia In illud: „In principium erat Verbum” (3, PG 31, 480A) wskazuje jasno, że Ewangelista na początku swojego dzieła użył określenia „Słowo”, aby wskazać na kolejną definicję osoby Chrystusa jako Syna Bożego. Należy ową definicję rozumieć w świetle pojęcia Logosu.

${ }^{103} \mathrm{~W}$ refleksji Bazylego idea konieczności zbawienia po upadku Adama miała podstawowe
} 
dzialnych. On przyszedł w ciele, aby z nim także ciało zostało wywyższone. Niewidzialny z widzialnym, aby podporządkować się temu, co widzialne jako człowiek - w czasie, jako Bóg - poza czasem"104.

Biskup Cezarei formułuje całą serię paralelizmów stanowiących główne wątki jego wizji chrystologicznej.

„[Syn] był Bogiem, stał się człowiekiem, według ekonomii zbawczej ${ }^{105}$. Nie najpierw «stał się», a potem «był»; ale najpierw «był» a dopiero potem «stał się». To, co dokonało się ze względu na dzieło zbawienia, niech nie wyklucza bóstwa Jednorodzonego"106.

Kapadocczyk wykazuje tutaj szczególne staranie o uwydatnienie kolejności i znaczenia poszczególnych czasowników występujących w prologu Janowym. Bierze pod uwagę bóstwo Chrystusa i jego istnienie ab aeterno, odwołując się do czasownika en. Daje do zrozumienia, że sformułowanie „stało się

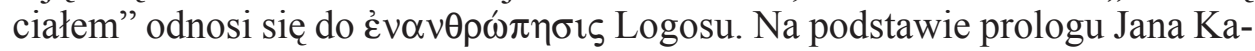
padocczyk ustalił różnice w terminologii, ukazując fakt preegzystencji Syna i Jego wcielenie ${ }^{107}$.

Według opinii biskupa Cezarei wszyscy negujący biblijne przekazy o przyjściu Logosu w ciele ${ }^{108}$, burzą Boży zamysł zbawienia i czynią bezowocną łaskę płynącą z faktu wcielenie Syna Bożego. Przyjęcie prawdy objawionej w Słowie Bożym jest niezbędną koniecznością. Przyjście Pana w cie$\mathrm{le}^{109}$, opisane przez natchnione teksty jest ukazaniem się par excellence Boga transcendentnego i ukrytego. Tajemnica wcielenia objawia się w kontynuacji historii zbawienia i jest wypełnieniem tajemnicy ,zapowiedzianej przed wiekami i oznajmionej przez proroków"110. Ten syntetyczny i jednocześnie głęboki opis wcielenia Zbawiciela zostaje dopełniony niektórymi znaczącymi cytatami biblijnymi, które ujawniają fundamentalne aspekty tej tajemnicy.

znaczenie. Por. tenże, Homilia in Psalmum XLVIII 3-4, PG 29, 437B - 441C; tenże, Regulae fusius tractatae 2, PG 31, 908B - 916C.

${ }^{104}$ Tenże, Homilia adversus eos qui per calumniam dicunt dici a nobis tres Deos esse 4, PG 31, 1493C, tłum. własne.

${ }^{105}$ Chodzi o działanie Boże w stosunku do świata i człowieka.

${ }^{106}$ Tenże, Homilia adversus eos qui per calumniam dicunt dici a nobis tres Deos esse 4, PG 31, 1496A, thum. własne.

${ }^{107}$ Podobnie Orygenes w: Commentarii in Iohannem II 1, 10, éd. C. Blanc, SCh 120, Paris 1966, 212-215, thum. S. Kalinkowski: Orygenes, Komentarz wedlug św. Jana, ŹMT 27, Kraków 2003, 85.

${ }^{108}$ Por. Basilius Caesariensis, Epistula 261, 2, Courtonne, III, s. 116-117, thum. Krzyżaniak, s. 322-324.

${ }^{109}$ To określenie dzięki swemu biblijnemu wydźwiękowi i znaczeniu tradycyjnie było stosowane jako tytuł chrystologiczny. Począwszy od Klemensa Aleksandryjskiego wszyscy pisarze szkoły aleksandryjskiej używali często tego słowa. Ich śladem poszli Kapadocczycy i inni autorzy kościelni. Bogaty wybór przykładów tego typu można znaleźć się w: Lampe, s. 520-522.

${ }^{110}$ Basilius Caesariensis, Homilia in sanctam Christi Generationem 4, PG 31, 1465B, thum. własne. 
Biskup Cezarei uważa, że to litość ku ludziom stały się powodem, iż Pan zechciał uczestniczyć w słabości ludzkiej i zniżył się aż do cielesnej nędzy ${ }^{111}$. Dla Kapadocczyka wcielenie Słowa to paradoksalne spotkanie i zjednoczenie rzeczywistości z sobą sprzecznych, które dzięki mocy Bożej stały się jednością $^{112}$. Dostrzec można także inne, bardziej precyzyjne założenie. Ciało Chrystusa i jego poddanie się ludzkim odruchom, ukazują rzeczywiste aspekty Jego wcielenia. ,„[Chrystus] ukazał współuczestnictwo w ludzkiej naturze i uwolnił nas od krańcowych [odruchów]: nie pozwalając poddawać się impulsom, ani nie pozostawać obojętnymi na nieszczęścia"113. Jednak Zbawcy nie dotknęły te rodzaje cierpień, które spowodowała skażona i zraniona ludzka natura.

Bazyli wskazuje na to, że wiele Psalmów zapowiada wcielenie Chrystusa. Koncentruje swoją uwagę na wersecie Ps 45, 5 i twierdzi: „Ciało Chrystusa zostało uświęcone $\mathrm{z}$ powodu zjednoczenia $\mathrm{z}$ bóstwem. $\mathrm{Z}$ tego rozumiemy, że przybytkiem Najwyższego jest objawienie się Boga w ciele"114. Kapadocczyk zatrzymuje się na znaczeniu słowa ,przybytek” (namiot). Dzieje się tak, ponieważ Apolinary w swoich refleksjach na temat J 1, 14 mówił o ciele Chrys-

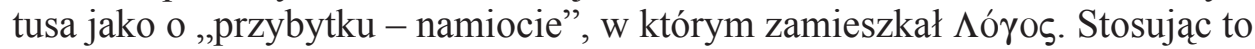
samo porównanie, biskup-mnich mówił o namiocie jako sanktuarium Boga Najwyższego. Jest to figura niosącego bóstwo ciała, które przyjął $\Lambda$ ó $\varsigma^{115}$.

W egzegezie Psalmów biskup Cezarei Kapadockiej zwracał uwagę na łaskę i Boże błogosławieństwo dane na wieki. Ten typ refleksji w Ps 44, 3 prowadzi Bazylego do tego, by zająć się aspektami człowieczeństwa Chrystusa. Czyni to analogicznie do egzegezy innych tekstów biblijnych (por. Łk 2, 52; Ps 44, 8 i Flp 2, 8-9). Te wersety to tradycyjne teksty kontrowersji ariańskiej ${ }^{116}$.

„«Pobłogosławił tobie Bóg na wieki», rzecze (Ps 44, 3). Jest zrozumiałe, że należy to odnieść do człowieczeństwa, jak i [werset]: «Czynił postępy w mądrości, w latach i w łasce» (Łk 2, 52). Według tego uważamy, że łaska została $\mathrm{Mu}$ dana jakoby [w formie] nagrody za nieskazitelne czyny. Podobny do tego

${ }^{111}$ Por. tenże, De Spiritu Sancto VIII 18, 1-45, SCh 17bis, 306-311, thum. Brzóstkowska, s. 105107. Odnośnie do terminologii zob. SCh 17bis, 308-309.

112 Tenże, De baptismo I 2, éd. U. Neri - J. Ducatillon, SCh 357, Paris 1989, 100-101, thum. własne.

${ }^{113}$ Tenże, Homilia IV: De gratiarum actione 5, PG 31, 228C, thum. własne, por. także: tenże, Epistula 261, 3, ed. Courtonne, III, s. 117-119, tłum. Krzyżaniak, s. 324-325.

114 Tenże, Homilia in Psalmum XLV 5, PG 29, 424A, tłum. własne.

${ }^{115}$ W interpretacji J 1, 14 Apolinary mówi o ciele Chrystusa jako „namiocie”, w którym zamieszkuje Boski Logos. Por. jeden z fragmentów cytowanych przez Simonettiego w: Il Cristo, vol. 2: Testi teologici e spirituali in lingua greca dal IV al VII secolo, a cura di M. Simonetti, Scrittori Greci e Latini, [Roma - Milano], 318-319 (tekst gr. Lietzmann, Apollinaris von Laodicea, s. 204).

${ }^{116}$ Śladem Bazylego poszedł Hieronim (Tractatus sive Homiliae in Psalmum XV 7, 340-341, ed. G. Morin, CCL 78, Turnhout 1968, 375 [Łk 2, 52]; tamże CVIIII 7, 232, CCL 78, 229 [Flp 2, 9]; tamże CXXXII 2, 58-60, CCL 78, 278 [Ps 44, 8]; tenże, Epistula 65, 9, 1, ed. I. Hilberg, CSEL 54, Vindobonae 1910, 625, 21-23. Zob. M.C. Paczkowski, Girolamo e la polemica antiapollinarista, „Antonianum” 79 (2004) 486-488. 
[wersetu] jest także ten: «Miłujesz sprawiedliwość, wstrętna ci nieprawość, dlatego Bóg, twój Bóg, namaścił ciebie olejkiem radości hojniej niż równych ci losem» (Ps 44, 8). Podobnie [brzmi] to, co napisał [apostoł] Paweł do Filipian: «Uniżył samego siebie, stawszy się posłusznym aż do śmierci - i to śmierci krzyżowej. Dlatego też Bóg Go nad wszystko wywyższył» (Flp 2, 8-9). To wszystko powiedziano o Zbawicielu jako człowieku"117.

Bazyli w nieco nieszablonowy sposób nawiązuje do doskonałości moralnej Zbawiciela. Jednak paradoksy stawania się człowiekiem przez odwieczne Słowo to jakby zasypywanie przepaści pomiędzy naturą ludzką i boską. Różnica zostaje zniwelowana dzięki mocy i potędze Logosu. Sformułowania użyte przez komentatora pozwalają na złagodzenie paradoksalnych pojęć używanych wcześniej w opisie wcielenia i jego konsekwencji.

Po podsumowaniu wcześniejszego etapu swojej egzegezy Kapadocczyk kontynuuje swoje rozważania:

„Do tej pory [psalmista] brał pod uwagę wiele rzeczy, kierując wzrok na człowieczeństwo [Chrystusa]. Teraz natomiast przystępuje do opisywania wielkości chwały Jednorodzonego"118.

Komentator brał pod uwagę najważniejsze aspekty człowieczeństwa Zbawiciela tylko w Ps 44, 3. Jednak, podobnie jak w innych przypadkach, jego egzegeza ma charakter chrystologiczny, chociaż tekst był analizowany głównie pod kątem trynitarnym ${ }^{119}$.

Fakt powrotu do refleksji na temat człowieczeństwa Chrystusa z punktu widzenia metodologicznego jest uzasadniony poprzez przywołanie podstawowej zasady teologicznej dotyczącej Jego osoby i wcielenia.

„Ponieważ mowa na temat Zbawcy jest złożona z powodu natury Jego bóstwa i ekonomii wcielenia, [psalmista] skierował na nowo spojrzenie ku człowieczeństwu Boga, mówiąc: «Miłujesz sprawiedliwość, wstrętna ci nieprawość»» (Ps 44, 8). Należy to [rozumieć następująco]: podczas gdy inni ludzie z trudem i przy pomocy ascezy oraz starania często zachowują skłonność do piękna [moralnego], [ale i] oddalania się od rzeczy nierozumnych, dla Ciebie ${ }^{120}$ natomiast [właściwa] jest pewnego rodzaju fizyczna zażyłość z dobrem i pięknem oraz niechęć do nieprawości""121.

Wprowadzenie o charakterze etycznym poprzedza dyskurs soteriologiczny. Aby dokonać zbawienia grzesznych ludzi, Chrystus nie mógł być splamiony grzechem. Na podstawie Pisma Świętego Bazyli nie tylko koryguje,

${ }^{117}$ Basilius Caesariensis, Homilia in Psalmum XLIV 3, PG 29, 397B-C, thum. własne.

${ }_{118}$ Tamże XLIV 7-8, PG 29, 404B.

119 Tak jest w przypadku Grzegorza z Nyssy, który analizuje Ps 44, 8 w Antirrheticus adversus Apollinarium 54, ed. F. Mueller, GNO 3/1, Leiden 1958, 223-226.

${ }^{120}$ Bazyli odwołuje się do człowieczeństwa Chrystusa, porównanego z innymi ludźmi.

${ }^{121}$ Basilius Caesariensis, Homilia in Psalmum XLIV 8, PG 29, 405A-B, thum własne. 
ale wręcz odrzuca radykalną pozycję apolinarystyczną, która nie przewidywała wymiaru etycznego działań Syna Bożego. Zamiarem Laodycejczyka było tak ściśle połączenie człowieczeństwa i bóstwa Chrystusa, by wyeliminować w Nim wymiar etyczny wyboru dobra. Bazyli, mimo iż stanowczo podkreślał jedność natur w osobie Słowa wcielonego, wskazywał także na to, że w Jego ludzkiej naturze dochodziły do głosu odruchy skłaniające ku dobru, także w sensie konkretnym. Ten element wydaje się decydujący, jeśli chodzi o kompleksową ocenę chrystologii Apolinarego i Bazylego.

W dziełach Bazylego Wielkiego można dostrzec ogólny kontekst rozwijającej się kontrowersji apolinarystycznej oraz rolę, jaką w niej odgrywały filozofia i egzegeza biblijna. Paradoksalnie apolinaryzm, przez swoje zaprzeczenie pełni człowieczeństwa wcielonego Logosu, stał się odwrotnością błędu negującego pełne bóstwo Syna Bożego. W kontekście polemicznym Kapadocczyk nie tylko rozwijał własną teologię, ale także starał się spenetrować pole problematycznej refleksji chrystologicznej, gdzie znalazł się Apolinary z Laodycei. W rozwiązywaniu antropologiczno-soteriologicznego problemu integralności człowieczeństwa Chrystusa, biskup Kapadocji odwoływał się do tradycji filozofów, przede wszystkim stoików i neoplatoników. Warto także zwrócić uwagę na interpretację biblijnych perykop, które miały na celu obalenie przekonań apolinarystów. Bazyli rozpoczął od opisu przekonań biskupa Apolinarego, jako bazujących na pełnych fantazji teoriach, które nie miały oparcia w Piśmie Świętym. Generalnie jednak Kapadocczyk preferował zachowywanie dystansu. Demaskował jednak błędy swoich oponentów, na podstawie właściwej interpretacji kluczowych fragmentów natchnionych ksiag. W swoich refleksjach i wyjaśnieniach Bazyli szczególnie podkreślał obecność duszy w Chrystusie, która była zdolna do odczuwania i cierpienia.

Jednostronna obrona jedności w Chrystusie ze strony apolinarystów prowadziła w efekcie do redukcji w Nim tego, co ludzkie, i takiej dominacji Słowa, że wiązała się z usiłowaniem uczynienia Boga wewnętrzną zasadą i cząstką tego świata. Nietrudno zauważyć, że za tym ujęciem kryło się typowo hellenistyczne rozumienie relacji istoty boskiej do świata, wyrażające

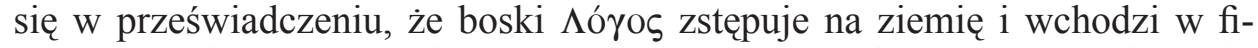
zyczną symbiozę z ziemskim ciałem. Przesłanki apolinarystyczne zdradzały na wskroś mitycznie rozumiany obraz świata i atmosferę intelektualną niektórych kręgów, przesiąkniętą jeszcze pogańskimi kategoriami. W doktrynie Apolinarego doszukiwano się próby hellenizacji chrześcijańskiej wiary. Według biskupa Cezarei niektóre z antropologicznych i filozoficznych zasad, do których odwoływał się Apolinary, jak również jego niewłaściwa interpretacja tekstów biblijnych uwydatniały dwuznaczności i słabość jego argumentacji. 
Bazyli wspominając osobę Apolinarego i jego zwolenników ukazuje ewolucję myśli teologicznej w 2. poł. IV w. Kapadocczyk przyczynił się do lepszego zrozumienia koncepcji, które pojawiły się za sprawą biskupa Laodycei. Rozprzestrzenianie się apolinaryzmu i ciosy zadawane głównym prawdom wiary chrystologicznej, sprawiły, że Bazyli nie mógł powstrzymać się od zabrania głosu. Jego refleksja zawiera elementy godne uwagi, przede wszystkim ze względu na wyodrębnienie tych perykop biblijnych, które najlepiej ukazywały znaczenie przyjęcia natury ludzkiej przez Boskie Słowo i pełni Jego człowieczeństwa. Kapadocczyk osiaga swój cel: uznanie w osobie Zbawcy obecności duszy ludzkiej ze wszystkimi konsekwencjami. To wydawało się w ówczesnej polemice wystarczające, gdyż było koniecznym uzupełnieniem kompleksowej refleksji nad osobą Jezusa Chrystusa, Boga-człowieka.

\section{THE COMPARISON BETWEEN BIBLE AND PHILOSOPHY IN CONTROVERSY WITH APOLLINARISM OF BASIL THE GREAT}

(Summary)

This article presents the role played by philosophy and biblical exegesis in controversy with Apollinarius of Laodicea. First of all it tries to present the general context of the dispute, then to develop Basil's theological thinking and apply it to the problematic Christological field, where Apollinarius directed his challenge. Faced with the anthropological-soteriological problem relating to the defence of the integrity of Christ's human nature, Basil draws on Stoic and Neoplatonic philosophical tradition. Then, this paper focuses attention on Basil's interpretation of some biblical passages in the confutation of Apollinaris' doctrine. Basil had started the controversy by describing Apollinarius as supporter of fabulous theories, which are not based on the Scriptures, and of Judaizing ideas which concerned the eschatological renewal. Generally, the Cappadocian prefers to distance himself from Apollinaris and does not intervene in complete manner on the theological debate. The bishop - monk tries to unmask the errors of the opponents' theories starting with the correct interpretation of the scriptural passages used by Apollinarius. In some points of his works, the Cappadocian insists that the Savior had a soul capable of feeling and suffering. According to the bishop of Caesarea some of anthropological and philosophical principles used by Apollinaris, along with the distorted reading of biblical texts, revealed the ambiguities and the inconsistencies of his arguments.

Key words: Basile the Great, Apollinarius of Laodicea, Christology, Patristic, philosophy, biblical interpretation.

Słowa kluczowe: Bazyli Wielki, Apolinary z Laodycei, chrystologia, patrystyka, filozofia, interpretacja biblijna. 


\section{BIBLIOGRAFIA}

\section{Źródła}

Apollinare, Epifanio, Gregorio Nazianzeno, Gregorio di Nissa e altri su Cristo. Il grande dibattito nel quarto secolo, testi originali, introduzione, note e traduzione a cura di E. Bellini, Di Fronte e Attraverso 35, Milano 1978.

Apollinarius, Epistula ad Dionysium, ed. H. Lietzmann, w: Apollinaris von Laodicea und seine Schule, TU, Tübingen 1904, 256-262.

Apollinarius, Recapitulatio, ed. H. Lietzmann, w: Apollinaris von Laodicea und seine Schule, TU, Tübingen 1904, 242-246.

Basilius Caesariensis, Adversus Eunomium, éd. B. Sesboüé - G.-M. de Durand - L. Doutreleau, SCh 299 i 305, Paris 1982 i 1983.

Basilius Caesariensis, Homiliae in Hexaemeron, éd. S. Giet, SCh 26bis, Paris 1968.

Basilius Caesariensis, Epistulae, ed. Y. Courtonne, I-III, Paris 1957-1966, thum. W. Krzyżaniak: Św. Bazyli Wielki, Listy, Warszawa 1972.

Basilius Caesariensis, De baptismo, éd. U. Neri, SCh 357, Paris 1989.

Basilius Caesariensis, De fide, PG 31, 676-692, tłum. J. Naumowicz, ŹM 5, Kraków Tyniec 2011², 91-105.

Basilius Caesariensis, De Spiritu Sancto, éd. B. Pruche, SCh 17bis, Paris 1968, thum. A. Brzóstowska: Św. Bazyli Wielki, O Duchu Świętym, wstęp J. Naumowicz, Warszawa 1999.

Basilius Caesariensis, Homilia I et II: De ieiunio, PG 31, 163-198.

Basilius Caesariensis, Homilia IV: De gratiarum actione, PG 31, 217-257.

Basilius Caesariensis, Homilia V: In martyrem Iulittam, PG 31, 237-262.

Basilius Caesariensis, Homilia IX: Quod Deus non est auctor malorum, PG 31, 329-353.

Basilius Caesariensis, Homilia XV: De fide, PG 31, 464-472.

Basilius Caesariensis, Homilia XVI: In illud: „In principium erat Verbum”, PG 31, 472-481.

Basilius CAESARIENSIS, Homilia adversus eos qui per calumniam dicunt dici a nobis tres deos esse, PG 31, 1488-1496.

Basilius CAesariensis, Homilia in sanctam Christi generationem, PG 31, 1457-1476, thum. W. Kania: Św. Bazyli, Homilia na Boże Narodzenie, Głos Tradycji 25, Tarnów 1992.

Basilius Caesariensis, Homiliae in Psalmos, PG 29, 209-493.

Basilius Caesariensis, Regulae brevius tractatae, PG 31, 1052-1305, thum. J. Naumowicz, w: Bazyli Wielki, Pisma ascetyczne, ŹM 6, Kraków - Tyniec 2011², 207-501.

Basilius Caesariensis, Regulae fusius tractatae, PG 31, 889-1052, tłum. J. Naumowicz, w: Bazyli Wielki, Pisma ascetyczne, ŹM 6, Kraków - Tyniec 2011², 57-203.

Basilio di Cesarea, Testi cristologici, a cura di G. Mazzanti, Cultura Cristiana Antica. Testi, Roma 1991.

Clemens Alexandrinus, Paedagogus, ed. O. Stählin - U. Treu, GCS 12, Berlin 1972, 89292, tłum. M. Szarmach: Klemens Aleksandryjski, Wychowawca, Torun 2012.

Epictetus, Diatriba, ed. W.A. Oldfather, LCL 131, I, Cambrigde MA - London 1959, tłum. L. Joachimowicz: Epiktet. Diatryby, Encheiridion z dodaniem Fragmentów oraz Gnomologium Epiktetowego, Warszawa 1961.

Epiphanius, Panarion haer. 65-80. De fide, ed. K. Holl - J. Dummer, GCS 37, Berlin 1985. Eusebius CAesariensis, De ecclesiastica theologia, ed. E. Klostermann, GCS 14, Leipzig 1906, 59-182. 
Gregorius Nazianzenus, Epistulae, PG 37, 21-388, tłum. J. Stahr: Grzegorz z Nazjanzu, Listy, POK 15, Poznań 1933.

Gregorius Nyssenus, Antirrheticus adversus Apollinarem, ed. F. Mueller, GNO 3/1, Leiden 1958, 131-233.

Gregorius Nyssenus, De instituto christiano, ed. W. Jaeger, GNO 8/1, Leiden 1952, 40-89.

Hieronymus, Commentariorum in Danielem libri III (IV), ed. F. Glorie, CCL 75A, Turnhout 1964.

Hieronymus, Epistulae, pars I: Epistulae I-LXX, ed. I. Hilberg, CSEL 54, Vindobonae 1910, tłum. J. Czuj i M. Ożóg: Hieronim, Listy, t. 1 (1-50) - 2 (51-70), tekst łaciński przygotował H. Pietras, ŹMT 54-55, Kraków 2010.

Hieronymus, Tractatus sive Homiliae in Psalmos, ed. G. Morin, editio altera, CCL 78, Turnhout 1958.

Il Cristo, vol. 2: Testi teologici e spirituali in lingua greca dal IV al VII secolo, a cura di M. Simonetti, Scrittori Greci e Latini, [Roma - Milano] 1986.

Iustinus, Apologia II, ed. J.C.Th. Otto, w: Corpus Apologetarum Christianorum saeculi secundi, I/1, Wiesbaden 1969, 194-243, tłum. L. Misiarczyk: Justyn Męczennik, 2 Apologia, w: Justyn Męczennik, 1 i 2 Apologia. Dialog z Żydem Tryfonem, Warszawa 2012, 91-100.

Origenes, Commentarii in Iohannem, t. 1: Livres I-V, éd. C. Blanc, SCh 120, Paris 1966, tłum. S. Kalinkowski: Orygenes, Komentarz do Ewangelii wedtug św. Jana, ŹMT 27, Kraków 2003.

Origenes, De principiis, t. 3: Livres III et IV, éd. H. Crouzel - M. Simonetti, SCh 268, Paris 1980, thum. S. Kalinkowski: Orygenes, O zasadach, PSP 23, Warszawa 1979.

Origenes, Contra Celsum, ed. P. Koetschau, GCS 3, Leipzig 1899, tłum. S. Kalinkowski: Orygynes, Przeciw Celsusowi, PSP 17/1-2, Warszawa 1977.

Philo Alexandrinus, De Cherubim, ed. F.H. Colson - G.H. Whitaker, w: Philo, [Works], with an English translation, vol. 2, LCL 227, Cambridge MA - London 1958, 8-85.

Philo Alexandrinus, De specialibus legibus, ed. F.H. Colson, w: Philo, Works, with an English translation, vol. 7-8, LCL 320 i 341, Cambridge MA - London 1958-1960.

Plato, Respublica, ed. C.F. Hermann, w: Plato, Dialogi, vol. IV, Lipsiae 1911, 1-317, tłum. W. Witwicki: Platon, Państwo z dodatkiem siedmiu ksiag „Praw”, t. 1-2, Warszawa 1958.

Plotinus, Enneades, ed. R. Volkmann, vol. 1-2, Lipsiae 1883-1884, thum. A. Krokiewicz: Plotyn, Enneady, t. 1-3, Warszawa 2000.

Simplicius, In Aristotelis Categorias commentarium, ed. C. Kalbfleisch, w: Simplicius, Commentaria in Aristotelem Graeca, vol. 8, Berolini 1907.

Simplicius, In Aristotelis De caelo commentaria, ed. I.L. Heiberg, w: Simplicius, Commentaria in Aristotelem Graeca, vol. 7, Berolini 1894.

Sophronius Hierosolymitanus, Encomium in sanctum Joannem Baptistam, PG 86/3, 3321-3353.

Sophronius Hierosolymitanus, Epistula Synodica ad Sergium, PG 87/3, 3148-3200.

\section{Opracowania}

BeEley Ch.A., The Early Christological Controversy: Apollinarius, Diodore, and Gregory Nazianzen, VigCh 65 (2011) 376-407.

Capone A., Apollinarismo e geografia ecclesiastica, w: Temi e forme della polemica in età cristiana (III-V secolo), a cura di M. Marin - M. Veronese, Auctores nostri 9, Bari 2012, 457-473.

CAPOne A., Apollinaris, Basil and Gregory of Nyssa, ZACh 17 (2013) 315-331. 
Cavalcanti E., Osservazioni sull'uso di Baruch 3, 36-38, w: Mémorial Dom Jean Gribomont (1920-1986), SEA 27, Roma 1988, 145-165.

Drecoll V.H., Die Entwicklung der Trinitätslehre des Basilius von Cäsarea. Sein Weg vom Homöusianer zum Neonizäner, Forschungen zur Kirchen und Dogmengeschichte 66, Göttingen 1996, 29-31.

Grillmeier A., Christ in Christian Tradition, transl. J. Bowden, London 1965.

Guinot J.-N., Théodoret et le millénarisme d'Apollinaire, ASE 15 (1998) fasc. 1, 153-180.

Kelly J.N.D., Poczatki doktryny chrześcijańskiej, thum. J. Mrukówna, Warszawa 1988.

Long A.A., A Stoic and Socratic Guide to Life, Oxford 2002.

Naumowicz J., Wcielenie Boga i zbawienie człowieka. Złota reguła soteriologii patrystycznej, WST 13 (2000) 17-30.

Paczkowski M.C., Girolamo e la polemica antiapollinarista, „Antonianum” 79 (2004) 473-504.

Perrone L., ,Four Gospels, Four Councils”- One Lord Jesus Christ. The Patristic Developments of Christology within the Church of Palestine, „Liber Annuus Studii Biblici Francescani" 49 (1999) 372.

Pohlenz M., Die Stoa. Geschichte einer geistigen Bewegung, Göttingen 1992.

Pyc M., Apolinaryzm w kontekście sporu o integralność człowieczeństwa Jezusa Chrystu$s a$, ,Teologia w Polsce” 6 (2012) fasc. 2, 5-16.

Reale G., Historia filozofii starożytnej, tłum. E.I. Zieliński, t. 4, Lublin 2005.

Simonetti M., Między dosłownościa a alegoriq. Przyczynek do historii egzegezy patrystycznej, tłum. T. Skibiński, Myśl Teologiczna 26, Kraków 2000.

Szewczyк P.M., Człowieczeństwo Logosu wedtug Atanazego Wielkiego, Myśl Teologiczna 65, Kraków 2010.

Tielman T., Chrisippus' On affections: Reconstruction and Interpretation, Boston 2003.

TUILIER A., Le sens de l'Apollinarisme dans les controverses théologiques du IV siècle, StPatr 13 (1975) 295-305.

VöGtLE A., Affekt, RACh I 160-173.

Wojciechowski M., Wprowadzenie, w: Atanazy z Aleksandrii, O wcieleniu Stowa, tłum. M. Wojciechowski, PSP 61, Warszawa 1998, 9-20.

Wolfson H.A., Philosophical Implications of Arianism and Apollinarianism, DOP 12 (1958) 3-28. 
